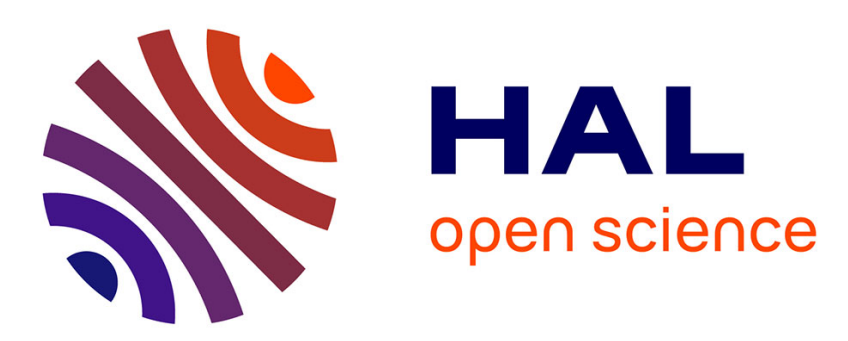

\title{
Henry's law constant measurements for formaldehyde and benzaldehyde as a function of temperature and water composition
}

\author{
Lyassine Allou, Lahcen El Maimouni, Stéphane Le Calvé
}

\section{To cite this version:}

Lyassine Allou, Lahcen El Maimouni, Stéphane Le Calvé. Henry's law constant measurements for formaldehyde and benzaldehyde as a function of temperature and water composition. Atmospheric Environment, 2011, 45 (17), pp.2991-2998. 10.1016/j.atmosenv.2010.05.044 . hal-02308857

\section{HAL Id: hal-02308857 https://hal.science/hal-02308857}

Submitted on 21 Dec 2020

HAL is a multi-disciplinary open access archive for the deposit and dissemination of scientific research documents, whether they are published or not. The documents may come from teaching and research institutions in France or abroad, or from public or private research centers.
L'archive ouverte pluridisciplinaire HAL, est destinée au dépôt et à la diffusion de documents scientifiques de niveau recherche, publiés ou non, émanant des établissements d'enseignement et de recherche français ou étrangers, des laboratoires publics ou privés. 


\section{Henry's Law Constant measurements for formaldehyde} and benzaldehyde as a function of temperature and water composition.

\title{
Lyassine Allou ${ }^{1}$, Lahcen El Maimouni ${ }^{2}$, Stéphane Le Calvé 1,*
}

${ }^{1}$ Laboratoire des Matériaux, Surfaces et Procédés pour la Catalyse (LMSPC, UMR 7515 CNRS/UdS), 25 rue Becquerel, 67087 Strasbourg Cedex 02, France

\author{
${ }^{2}$ Equipe Matériaux et Physicochimie des Milieux Naturels (MPM), Faculté des Sciences \\ d'Agadir, Université Ibn Zohr, BP 8106, cité Dakhla, 80000 Agadir, Maroc
}

\section{Abstract}

Henry's Law Constants $H$ of formaldehyde and benzaldehyde were determined using a dynamic system based on the water/air equilibrium at the interface within the length of a microporous tube. The measurements were conducted over the range $273-293 \mathrm{~K}$ in (i) deionized water, (ii) $35 \mathrm{~g} \mathrm{~L}^{-1}$ solution of $\mathrm{NaCl}$ simulating seawater and (iii) two nitric acid solutions, i.e. 0.63 and $6.3 \mathrm{wt} \%$.

In pure water, the obtained data were used to derive the following Arrhenius expressions: $\ln H=(6423 \pm 542) / T-(13.4 \pm 2.0)$ and $\ln H=(6258 \pm 280) / T-(17.5 \pm 1.0)$ for formaldehyde and benzaldehyde, respectively. The $H$ values, calculed at $293 \mathrm{~K}$ from Arhenius expressions cited bellow, were the following (in units of $\mathrm{M} \mathrm{atm}^{-1}$ ) :H=5020 \pm 1170 (formaldehyde), $H=47 \pm 5$ (benzaldehyde). The temperature dependence of $H$ permits then to derive the solvation enthalpies for both compounds : $\Delta H_{\text {solv }}=-(53.4 \pm 4.5) \mathrm{kJ} \mathrm{mol}^{-1}$ and $\Delta H_{\text {solv }}$ $=-(52.0 \pm 2.3) \mathrm{kJ} \mathrm{mol}^{-1}$ for formaldehyde and benzaldehyde, respectively.

In $35 \mathrm{~g} \mathrm{~L}^{-1}$ salt solution, the $H$ values were 27 to $66 \%$ and 12 to $21 \%$ lower than their respective determinations in deionised water, for formaldehyde and benzaldehyde respectively. The observed salt effect was used to estimate the following Setschenow coefficients at $293 \mathrm{~K}$ for $0.6 \mathrm{M} \mathrm{NaCl}$ : formaldehyde (0.21) and benzaldehyde (0.09). 
In 6.3 wt $\%$ nitric acid solution, $H$ values of benzaldehyde were approximately $30 \%$

29 higher than those found in pure water although no significant influence was observed for 30 formaldehyde.

31 Finally, our experimental data were then used to estimate the fractions of formaldehyde

32 and benzaldehyde in atmospheric aqueous phase and their derived atmospheric lifetimes.

33

34 Keywords: Henry's law constant, formaldehyde, benzaldehyde, temperature, salinity, acidity, 35 salt effect, nitric acid.

36

37

38 * Corresponding author. Tel.: 33-3-68-85-03-68; fax: 33-3-68-85-04-02.

39 E-mail address: slecalve @ unistra.fr (S. Le Calvé)

40 


\section{Introduction}

Aliphatic and aromatic aldehydes constitute an abundant class of volatile organic compounds (VOCs) encountered in air and precipitations (rain, fog). Aldehydes are emitted into the atmosphere as primary pollutants from motor vehicles and industrial emissions, or produced in situ as environmentally intermediates in the photooxidation of other hydrocarbons (Atkinson, 1994; Müller, 1997). They play a key role in the tropospheric chemistry, since they lead photochemically to many products such as radical species that contribute to ozone $\left(\mathrm{O}_{3}\right)$ and nitrate acetic peroxy (PAN) productions (Atkinson, 2000).

Formaldehyde (FA) and benzaldehyde (BA) represent the dominant species of aliphatic and aromatic carbonyl compounds, respectively.

Formaldehyde is an atmospherically relevant carbonyl compound with an active and important role in the tropospheric photochemistry (Smith et al., 2006). It is formed in the oxidation pathways of many biogenic and anthropogenic VOCs (Sprengnether et al., 2002) and emitted directly from biomass fires. It is an efficient precursor of $\mathrm{HO}_{\mathrm{X}}$ radicals $\left(\mathrm{OH}\right.$ and $\left.\mathrm{HO}_{2}\right)$ which are the major tropospheric oxidant. Formaldehyde is also the main contributor to catalytic ozone loss in the lower stratosphere (McElroy et al., 1992). In addition, formaldehyde affects strongly the capacity of atmosphere waters (fog, clouds) because it inhibits the oxidation of S(IV) to sulfuric acid and because it is a precursor of formic acid (Khare et al., 1997; Kieber et al., 1999; Munger et al., 1986).

Consequently, gaseous formaldehyde concentrations have been measured at different locations. Field measurements have shown concentration of $0.05 \mathrm{ppbv}$ in clean Antarctic tropospheric air in winter (Riedel et al., 1999), a value varying between 15 and 20 ppbv in London (Williams et al., 1996) and up to 70 ppbv in Los Angeles (Williams et al., 1996).

Benzaldehyde can be considered as a model of simple aromatic aldehydes. It can be found in fruit, and is used as a soil fumigant and in the manufacturing of deodorants/air fresheners and loose mineral wool fiber (Atkinson, 1994).

Both FA and BA are polar molecules having high solubilities in water and are expected to be efficiently scavenged from the gas phase by rain and fog (Gunz and Hoffmann, 1990; Jayne et al., 1996). Significant levels of formaldehyde ranging between 0.01 and $13 \mu \mathrm{M}$ were found in rain and fog (Gunz and Hoffmann, 1990; Jayne et al., 1996) confirming its efficient scavenging from gas phase. Atmospheric deposition represents a significant sink since its 
concentrations in rain water are approximately three orders of magnitude higher than those in surface waters (Nuccio et al., 1995).

The partitioning of a given species between the gas and aqueous phases is given by its Henry's law constant $H$. This latter is a key physical characteristic to describe the behavior of a component in the environment (Rice et al., 1997) particularly in order to better understand its fate, its transport, and its removal in the lower troposphere. A detailed inspection of literature data shows a substantial variation in the previous quoted values for formaldehyde (Betterton and Hoffmann, 1988; Chameides, 1984; Gaffney and Senum, 1984; Seinfeld, 1986; Seyfioglu and Odabasi, 2007; Staudinger and Roberts, 1996; Warneck, 1988; Zhou and Mopper, 1990) whereas only few determinations have been reported in the cas of benzaldehyde (Allen et al., 1998; Betterton and Hoffmann, 1988; Gaffney and Senum, 1984; Hine and Mookerjee, 1975; Staudinger and Roberts, 1996; Zhou and Mopper, 1990). In addition, only few determinations have been obtained as a function of the water composition for both compounds.

In this study, direct experimental determinations of $H$ for both formaldehyde and benzaldehyde in pure water have been therefore performed via a dynamic equilibrium system between 273 and $293 \mathrm{~K}$. The effects on Henry's law constant of a $35 \mathrm{~g} \mathrm{~L}^{-1}$ solution of $\mathrm{NaCl}$ simulating seawater or 0.63 and $6.3 \mathrm{wt} \%$ nitric acid solutions chosen as maximal concentrations of $\mathrm{HNO}_{3}$ reported in tropospheric cloud droplets (Gao et al., 2004), have been investigated over the same temperature range. Our experimental determinations have been then compared with literature data and used to discuss the atmospheric lifetimes of both aldehydes. 


\section{Reagents}

Aqueous solutions of formaldehyde and benzaldehyde were prepared using Milli-Q Water $(18 \mathrm{~m} \Omega \mathrm{cm})$. Pure benzladehyde (GC grade, $\geq 99 \%)$ and aqueous formaldehyde solution (30\%) were obtained from Fluka Chemical Company and used without further purification. Sodium chloride $(\geq 99.8 \%)$ was obtained from Riedel-de Haën Chemical Company. The aqueous concentrations used for the experiments were in the range $13.7-97.6 \mathrm{mg} \mathrm{L}^{-1}$ for formaldehyde and $8.7-50.5 \mathrm{mg} \mathrm{L}^{-1}$ for benzaldehyde, given that their water solubilities are $55 \times 10^{4} \mathrm{mg} \mathrm{L}^{-1}$ (at $293 \mathrm{~K}$ ) and $0.46 \times 10^{4} \mathrm{mg} \mathrm{L}^{-1}$ (at $298 \mathrm{~K}$ ), respectively. To investigate the effects of acidity and salinity on $H$ values, aqueous solutions of containing either $0.63-6.3$ wt $\%$ of $\mathrm{HNO}_{3}$ or $35 \mathrm{~g} \mathrm{~L}^{-1}$ of $\mathrm{NaCl}$ were used.

\section{Dynamic equilibrium system}

The measurements of $H$ were conducted using a dynamic equilibrium system shown in Figure 1 and already used in previous work (Feigenbrugel et al., 2004a; Feigenbrugel et al., 2004b; Gautier et al., 2003; Katrib et al., 2003). Compressed air was passed through a microporous PTFE membrane tube $(180 \mathrm{~cm} \times 0.8 \mathrm{~cm}$ i.d., Sumitomo Corporation $)$ at a highly controlled flow rate of $0.2-0.5 \mathrm{~L} \mathrm{~min}^{-1}$. The tube was immersed in about $1.0 \mathrm{~L}$ of the diluted aqueous solution containing either formaldehyde or benzaldehyde. Phase equilibrium was achieved, for the dissolved compound, at the gas/water interface along the inner surface of the tube. The contact time between the two phases varied between 7 and $36 \mathrm{~s}$ depending on the flow rate. At the exit of the reactor, the gas phase containing the studied compound at equilibrium concentration was then diluted using clean dry air $\left(0.5 \mathrm{~L} \mathrm{~min}^{-1}\right)$. The compound present in the gas phase was trapped using two cartridges connected in series and filled with a 2,4-dinitrophenylhydrazine (2,4-DNPH) coated silica gel as derivatises. Benzaldehyde was collected for $20-60$ min whereas intervals of 4 to 6 hours were required to concentrate enough formaldehyde in cartridges.

After sampling, aldehyde was eluted three times by passing $20 \mathrm{~mL}, 10 \mathrm{~mL}$ and $10 \mathrm{~mL}$ of acetonirile through the cartridge. The mass of acetonitrile which stayed in the cartridge was measured after each extraction in order to know the dead volume in the cartridge. The experiments revealed that for benzaldehyde more than $97 \%$ of the compound was trapped in 
124 the first cartridge while for formaldehyde the percentage was about $92 \%$. It should be noted 125 that the mass of aldehyde trapped in the cartridges was always negligible compared to their 126 total mass in the aqueous solution and consequentely, their aqueous concentration were effectively constant during the course of the experiment.

128

\section{Analysis}

The extracted solutions containing the hydrazones were weighed and analysed by HPLC/UV. For this, $20 \mu \mathrm{L}$ of the extracted solution containing the hydrazones were injected into a reversed-phase column C-18 and were detected at a $360 \mathrm{~nm}$ wavelength (Marchand et al., 2006; Marchand et al., 2008). The hydrazones were separeted with a mobil phase of acetonitrile-water (60/40) isocratically pumped at a flow-rate of $1.5 \mathrm{~mL} \mathrm{~min}^{-1}$ and quantified from external calibration curves (Marchand et al., 2008). For this, both aldehyde derivatives were prepared according to the method previously described (Levart and Veber, 2001). Known concentrations of hydrazone were then prepared in acetonitrile and $20 \mu \mathrm{L}$ of the obtained solution were then injected into the HPLC in order to plot concentration curves versus HPLC peak areas. The calibration curves were linear for the concentration ranges used in this study i.e. between 0.1 and $25 \mathrm{mg} \mathrm{L}^{-1}$ for hydrazone solutions and the correlation coefficients were larger than 0.99 . Note that for each series of measurements, two blank cartridges of 2,4-DNPH were used to determine the background aldehydes concentrations.

\section{Results and discussion}

\section{Effect of temperature}

The Arrhenius plots of the Henry's Law Constants measured for benzaldehyde and formaldehyde in deionized water for a temperature range 273-293 K are presented in Figures 2 and 3. The $H$ values (in $\mathrm{M} \mathrm{atm}^{-1}$ ) are also listed in Table 1 where the quoted uncertainties vary between 8 and $20 \%$. These values represent the sum of the uncertainties on the calibration curves (ranging from $1 \%$ to $9 \%$ for formaldehyde and $1 \%$ to $7 \%$ for benzladehyde), on the extraction process estimated to be around of $5 \%$ by a series of reproductibility tests, on the flow rates (less than $2.5 \%$ under our experimental conditions) and on the aqueous concentration of the formaldehyde and benzaldehyde (up to 3\%). Within these experimental errors, $H$ values of both aldehydes are shown to be not sensitive to their aqueous concentration over the ranges stated in the experimental section and to the changes in 
155 air flow rate $\left(0.2-0.5 \mathrm{~L} \mathrm{~min}^{-1}\right)$ as shown in Figure 4. Since $H$ does not not vary with contact time, the equilibrium between solution and vapour is really achieved at the exit of reactor.

In Tables 2 and 3, our experimental $H$ values obtained at $293 \mathrm{~K}$ and those calculated at $298 \mathrm{~K}$ for formaldehyde and benzaldehyde respectively, are compared with previous determinations and estimated values reported in the literature.

For formaldehyde (see Table 2) and in spite of the different techniques used, our value of $H$ agrees raisonably well, within experimental errors, with those reported by Betterton et Hoffmann (1988), Zhou and Mopper (1990) and Staudinger and Roberts (1996). However, our $H$ value of $3500 \pm 900 \mathrm{M} \mathrm{atm}^{-1}$ (calculated at $298 \mathrm{~K}$ ) is 4 times lower than that reported by Warneck (1998) and approximately 2 times lower than those determined by Seinfeld (1986) or Gaffney and Senum (1984). Figure 2 shows our obtained data compared with previous experimental ones.

For benzaldehyde, our average $H$ value of $47 \mathrm{M} \mathrm{atm}^{-1}$ calculated at $298 \mathrm{~K}$ is in very good agreement with the previous ones reported by several studies (Allen et al., 1998; Betterton and Hoffmann, 1988; Gaffney and Senum, 1984; Hine and Mookerjee, 1975; Staudinger and Roberts, 1996; Zhou and Mopper, 1990) as illustrated in Table 3. However, as shown in Figure 3, the values of $H$ at low temperatures and particularly that obtained at $273 \mathrm{~K}$ are significantly higher than those reported by Betterton and Hoffmann (1988), Zhou and Mopper (1990) or Staudinger and Roberts (1996), but are similar, within experimental errors, to those recently obtained by Allen et al. (1998).

The following Arrhenius expressions can be derived from our data using a weighted analysis fit: $\ln H(\mathrm{FA})=(6423 \pm 542) / T-(13.4 \pm 2.0) ; \ln H(\mathrm{BA})=(6258 \pm 280) / T-(17.5 \pm$ 1.0). The quoted errors are given at the $2 \sigma$ level from the least-squares analysis. Our recommended $H$ values at $293 \mathrm{~K}$, derived from the Arrhenius expressions using a weighted analysis fit, are the following (in units of $\mathrm{M} \mathrm{atm}^{-1}$ ) $: H_{\mathrm{FA}}=5020 \pm 1170$ and $H_{\mathrm{BA}}=47 \pm 5$. The quoted errors correspond to $2 \sigma$ level and are determined from the standard deviations on both slope and intercept of Arrhenius expression. In addition, the temperature dependence are very similar for the two studied compounds meaning that their enthalpies of solvation are approximately the same.

The behaviour of henry's law constants as a function of temperature can be conveniently expressed with a Van't Hoff equation:

$$
H(\mathrm{~T})=H_{293} \times \exp \left(-\Delta H^{\circ} \text { solv } / \mathrm{R}(1 / T-1 / 293)\right)
$$


where $\Delta H^{\circ}$ solv is the solvation enthalpy $\left(\mathrm{J} \mathrm{mol}^{-1}\right), T$ is the temperature $(\mathrm{K})$ and $\mathrm{R}$ is the ideal gas constant. Assuming that $\Delta H^{\circ}$ solv is not temperature dependent between 273 and $293 \mathrm{~K}$, the values of $\Delta \mathrm{H}^{\circ}$ solv for both constituents have been calculed from a plot of $\ln H$ versus $1 / T$, where the slope is $-\Delta H^{\circ}{ }_{\text {solv }} / \mathrm{R}$. The linearity of these plots, within experimental uncertainties confirms the validity of equation (1). The derived enthalpies of solvation are the following (in units of $\left.\mathrm{kJ} \mathrm{mol}^{-1}\right): \Delta H^{\circ}$ solv $(\mathrm{FA})=-(52.0 \pm 4.5)$ and $\Delta H^{\circ}$ solv $(\mathrm{BA})=-(52 \pm 2.3)$ where the quoted errors correspond to $2 \sigma$ obtained from the least-squares analysis.

\section{Effect of nitric acid}

The measured $H$ values of formaldehyde and benzaldehyde in $0.63-6.3 \mathrm{wt} \%$ nitric acid solutions (maximal acid concentrations of tropospheric cloud droplets) in the range $273-293$ $\mathrm{K}$ for $\mathrm{HNO}_{3} 0.63 \mathrm{wt} \%(0.1 \mathrm{~N})$ and $268-293 \mathrm{~K}$ for $\mathrm{HNO}_{3} 6.3 \mathrm{wt} \%(1 \mathrm{~N})$, are reported in Figures 5 and 6.

As shown in Figure 6, the experimental Henry's law constants of benzaldehyde are approximately the same for pure water and the lower nitric acid concentration of $0.63 \mathrm{wt} \%$. Nevertheless, all $H$ values of benzaldehyde in $6.3 \mathrm{wt} \%$ nitric acid solution were $30 \%$ higher than their respective values in deionised water. In opposite to benzaldehyde, Henry's law constants of formaldehyde in both nitric acid solutions are approximately the same than those measured in pure water, as displayed in Figure 5.

The question, of course, arises as to why a such difference is observed between the formaldehyde and benzaldehyde uptake behavior in acid medium. First, let us remind that in liquid solution, aldehydes ( $\mathrm{RCHO})$ react with water to form gem diol $\left(\mathrm{RCH}(\mathrm{OH})_{2}\right.$ aq $)$ which is greatly more water-soluble than its precursor. This hydratation pathway increases effective aldehyde solubility in water since its hydratation coefficient $k_{\text {hyd }}$ is very higher (in case of FA, $k_{\text {hyd }} \approx 2000$ at $298 \mathrm{~K}$ ) (Betterton and Hoffmann, 1988) but smaller for larger molecules $\left(\mathrm{k}_{\mathrm{hyd}}=\right.$ 7.7 at $298 \mathrm{~K}$ for phtalaladehyde (McDonald and Martin, 1979). The partitioning between gas and aqueous phases is then governed by the equilibrium constants as illustrated as follows:

$$
\mathrm{RCHO}_{(g)} \stackrel{H}{\longleftrightarrow} \mathrm{RCHO}(\mathrm{aq}) \stackrel{k_{\text {hyd }}}{\longleftrightarrow} \mathrm{RCH}(\mathrm{OH})_{2 a q}
$$

Therefore, hydratation subsequently increases the effective Henry's Law Constant of aldehydes. For formaldehyde, this effect can be expressed by the following equation: 


$$
H_{e f f}=\frac{\left[\mathrm{HCHO}_{a q}\right]+\left[\mathrm{CH}_{2}(\mathrm{OH})_{2 a q}\right]}{\left[\mathrm{HCHO}_{g}\right]}=H \times\left(1+k_{\text {hyd }}\right)
$$

If the medium is strongly acid, an additional way affects the set of equilibriums mentioned above (see Eq. 2) since a protonated form of aldehydes $\mathrm{RCH}_{2} \mathrm{O}^{+}$is formed as 220 shown below:

$$
\mathrm{RCHO}_{\mathrm{aq}}+\mathrm{H}^{+} \longleftrightarrow \mathrm{RCH}_{2} \mathrm{O}^{+}
$$

In this latter equation, the stability of $\mathrm{RCH}_{2} \mathrm{O}^{+}$cation strongly depends on the nature of alkyl group R.

As expected, our measured $H$ value of benzaldehyde is quite low in pure water, confirming that its value of $k_{\text {hyd }}$ is relatively limited, similarly to phtalaladehyde (McDonald and Martin, 1979). This is in agreement with the observations made by McDonald and Martin (1979) who concluded that no hydratation was detected for benzaldehyde.

At low acidity, the protonated form $\mathrm{RCH}_{2} \mathrm{O}^{+}$is still negligible as it was observed by Jayne et al. (1992) for both formaldehyde and acetaldehyde. In very low pH, our results suggest that the protonated form seems to be important and partially governs the partitioning of benzaldehyde between the gas and liquid phases.

The equilibrium (4) leads to the soluble cation $\mathrm{RCH}_{2} \mathrm{O}^{+}$which is thermodynamically more stable when $\mathrm{R}$ is an efficient electron donor group such as a phenyl group (benzaldehyde). In opposite to benzaldehyde, $\mathrm{HCH}_{2} \mathrm{O}^{+}$is unstable and break up quickly to regenerate $\mathrm{HCHO}_{\mathrm{aq}}$ so that the Henry's law constant of formaldehyde is not sensitive to the $\mathrm{pH}$ effect. However, at very low $\mathrm{pH}$, the decreasing of $\mathrm{H}_{2} \mathrm{O}$ activity reduces gem diol formation but supports inevitably the protonated form. Broadly, a compensation of the two effects takes place and finally, the observed Henry law constant does not undergo significant modification.

\section{Effect of salinity}

The Arrhenius plots of the Henry's Law Constants, measured for fomaldehyde and benzaldehyde in aqueous solutions of $\mathrm{NaCl}\left(35 \mathrm{~g} \mathrm{~L}^{-1}\right)$ simulating seawater for a temperature 
range $273-298 \mathrm{~K}$, are presented in Figures 7 and 8. The following Arrhenius expressions can be derived from our data using a linear fit: $\ln H_{\mathrm{S}}(\mathrm{FA})=(5548 \pm 1320) / T-(10.7 \pm 4.8)$ and $\ln H_{\mathrm{S}}(\mathrm{BA})=(6015 \pm 424) / T-(16.7 \pm 1.4)$. The quoted errors are given at the $2 \sigma$ level from the least-squares analysis.

As shown in both Figures 7 and 8, our $H$ values of benzaldehyde and formaldehyde in salt solutions were respectively 12 to $21 \%$ and $27 \%$ to $66 \%$ lower than their respective values in deionized water. For instance, the determined $H$ values at $293 \mathrm{~K}$ in salt solution obtained from Arrhenius expression given above, can be compared with those measured in pure water (in parentheses): formaldehyde, $H_{\mathrm{S}}=3770 \pm 2590(H=5020 \pm 1170)$; benzaldehyde, $H_{\mathrm{S}}=46 \pm$ $7(H=47 \pm 5)$ (in units of $\mathrm{M} \mathrm{atm}^{-1}$ ) where the quoted errors correspond to $2 \sigma$ obtained from the least-squares analysis. This phenomenon is related to the salting-out effect which impacts on the water solubility (reduction in solubility).

The salt effect on the solubility of gases in seawater has been studied theoretically for a variety of small gas molecules (Danckwerts, 1970). The presence of a salt in an aqueous solution changes the water structure in the vicinity of the solute. An empirical relation for the effect of ionic strength on a Henry's law constant $H$ for a given compound in an aqueous solution was given by (Setschenow, 1889):

$$
\log \left(H / H_{\mathrm{S}}\right)=h(\mathrm{NaCl})
$$

where $H$ and $H_{\mathrm{s}}$ are the Henry's law coefficients of the compound in pure water and in the salt solution, respectively, $(\mathrm{NaCl})$ is the molarity of the $\mathrm{NaCl}$ solution and $h$ is the Setschenow's salting-out coefficient $\left(\mathrm{L} \mathrm{mol}^{-1}\right)$. Our results of $H$ and $H_{\mathrm{S}}$ at $293 \mathrm{~K}$ were used to estimate the following Setschenow coefficients for $[\mathrm{NaCl}]=0.6 \mathrm{M}: h(\mathrm{FA})=0.21$ and $h(\mathrm{BA})=0.09$. The solubility at $293 \mathrm{~K}$ is then reduced by a factor of 0.34 and 0.13 for formaldhyde and benzaldehyde, respectively.

In the study performed in pure water and natural seawater by Zhou and Mopper (1990), the values of Setschenow's coefficients $h$ for benzaldehyde were found to be 0.20 and 0.15 at 298 and $283 \mathrm{~K}$, respectively. These values are relatively higher than that of 0.09 derived in this work at $293 \mathrm{~K}$. Besides, our $h$ value of formaldehyde disagrees with some observations made in previous studies (Dong and Dasgupta, 1986; Zhou and Mopper, 1990) since both studies report $H / H$ s ratios close to 1 . No salt effect on formaldehyde solubility have been detected by Dasgupta and Dong (1986) in their experiments conducted with aqueous solution containing 


$$
\tau_{\mathrm{A}, \text { multiphase }}=\frac{1+\mathrm{HRL}_{\mathrm{WC}} \mathrm{T}}{\mathrm{J}_{\mathrm{g}}+\mathrm{k}_{\mathrm{OHg}}[\mathrm{OH}]_{\mathrm{g}}+\mathrm{k}_{\mathrm{NO} 3 \mathrm{~g}_{\mathrm{g}}}\left[\mathrm{NO}_{3}\right]_{\mathrm{g}}+\mathrm{HRL}_{\mathrm{WC}} \mathrm{T} \times\left(\mathrm{J}_{\mathrm{aq}}+\mathrm{k}_{\mathrm{OH} \text { aq }}[\mathrm{OH}]_{\mathrm{aq}}\right)}
$$

\section{Atmospheric implications}

The distribution of soluble gases between the gaseous and droplet phases in the atmosphere is strongly dependent on their Henry's law constant.

Once released in the atmosphere, VOCs can react in the gas phase or can be taken up by liquid water in clouds where they can also be oxidized. For most of them, $\mathrm{OH}$ radical is the most efficient oxidizing species in both gas phase (Atkinson, 2000) and aqueous phase (Ervens et al., 2003). To evaluate the impact of a cloud on the atmospheric chemistry of formaldehyde and benzaldehyde, we compare in this section their atmospheric lifetimes under clear sky $\left(\tau_{\mathrm{gas}}\right)$ and cloudy conditions $\left(\tau_{\text {multiphase }}\right)$.

The lifetime of $\mathrm{A}$ in the gas phase $\left(\tau_{\mathrm{A}, \mathrm{gas}}\right)$ taking into account the photolysis and the reaction of $\mathrm{A}$ with $\mathrm{OH}$ and $\mathrm{NO}_{3}$ radicals, is defined as follows:

$$
\tau_{\mathrm{A}, \mathrm{gas}}=\frac{[\mathrm{A}]_{\mathrm{g}}}{-\mathrm{d}[\mathrm{A}]_{\mathrm{g}} / \mathrm{dt}}=\frac{1}{\mathrm{Jg}_{\mathrm{g}}+\mathrm{k}_{\mathrm{OHg}}[\mathrm{OH}]_{\mathrm{g}}+\mathrm{k}_{\mathrm{NO} 3 \mathrm{~g}}\left[\mathrm{NO}_{3}\right]_{\mathrm{g}}}
$$

where $\mathrm{J}_{\mathrm{g}}, \mathrm{k}_{\mathrm{OH}, \mathrm{g}}$ and $\mathrm{k}_{\mathrm{NO} 3, \mathrm{~g}}$ are respectively the gas-phase photolysis coefficient, the rate constant of the gas phase reaction of $\mathrm{OH}$ and $\mathrm{NO}_{3}$ radicals with $\mathrm{A},[\mathrm{OH}]_{\mathrm{g}}$ is the mean concentration of $\mathrm{OH}$ radicals and $[\mathrm{A}]_{\mathrm{g}}$ is the concentration of $\mathrm{A}$ in the troposphere. $\left[\mathrm{NO}_{3}\right]_{\mathrm{g}}$ is the night concentration of nitrate radicals.

If we consider now the cloudy atmosphere as a multiphase reactor where both gas and aqueous phases coexist, then the multiphase lifetime of A can be defined as (Monod et al., 2005): 
where $\mathrm{R}$ the ideal gas constant (in $\mathrm{L}$ atm $\mathrm{mol}^{-1} \mathrm{~K}^{-1}$ ), $\mathrm{L}_{\mathrm{wc}}$ the dimensionless liquid water content of the cloud (typically $4.2 \times 10^{-7}$ ) (Kolb, 1994), $\mathrm{J}_{\mathrm{aq}}$ and $\mathrm{kOH}_{\mathrm{O} \text {,aq }}$ are respectively the photolysis coefficient of $\mathrm{A}$ and the rate constant of $\mathrm{OH}$ reaction with $\mathrm{A}$ in aqueous phase, $[\mathrm{OH}]_{\mathrm{aq}}$ is the mean concentration of $\mathrm{OH}$ radicals in the tropospheric aqueous phase.

\section{The rate constants of $\mathrm{OH}$ reaction with formaldehyde or benzaldehyde in both aqueous} and gas phases have already been reported (Chin and Wine, 1994; IUPAC, 2009; NIST, 2009; Semadeni et al., 1995), and are shown in Table 4 together with the Henry's law constants determined in this work.

These data have then been used to estimate the partitioning and then the atmospheric lifetimes of both aldehydes under clear sky $\left(\tau_{\text {gas }}\right)$, and cloudy conditions ( $\left.\tau_{\text {multiphase }}\right)$, by using typical concentrations of $\mathrm{OH}$ radicals in gas and aqueous phases: $[\mathrm{OH}]_{\mathrm{g}}=1 \times 10^{6} \mathrm{~cm}^{-3}$ and $[\mathrm{OH}]_{\mathrm{aq}}=1 \times 10^{-13} \mathrm{M}($ Monod et al., 2005). We assume here that the $\mathrm{OH}$ concentration in the gas phase is the same under clear sky and cloudy conditions although it is reduced as soon as clouds are formed, and the magnitude of the decrease strongly depends on the $\mathrm{pH}$ value of the droplet (Monod and Carlier, 1999).

At $293 \mathrm{~K}$, the calculated aqueous fraction are the following: formaldehyde, $3.4 \times 10^{-2}$; benzaldehyde, $3.8 \times 10^{-4}$. At $293 \mathrm{~K}$ which is the temperature where most of experimental rate constants were measured, the atmospheric lifetimes of formaldehyde and benzaldehyde are slightly reduced in clouds as shown in Table 4. However, the average temperature of tropospheric clouds is $283 \mathrm{~K}$ and therefore, the calculated aqueous fraction of formaldehyde rises from $3.4 \times 10^{-2}$ to $9.6 \times 10^{-2}$ when the temperature decreases from 293 to $283 \mathrm{~K}$, temperature range where the $H$ value of formaldehyde increases from 5020 to $10900 \mathrm{M} \mathrm{atm}^{-1}$.

Assuming that the rate constants of $\mathrm{OH}$ reactions with formaldehyde or benzaldehyde in the gas and aqueous phases do not vary a lot between 283 and $298 \mathrm{~K}$ as it was already observed for many oxygenated VOCs (except when data are available at $283 \mathrm{~K}$ ), we can then estimate the multiphase lifetimes of both aldehydes at $283 \mathrm{~K}$. These calculated multiphase lifetimes at $283 \mathrm{~K}$ (in units of hours) can be compared to those under clear sky in July (in parentheses): formaldehyde, 7.0 (6.7) ; benzaldehyde, 1.2 (18.2). Considering all the uncertainties associated with the above calculations, one can conclude that the oxidation of formaldehyde might be negligible in aqueous phase although that of benzaldehyde could represent its main sink. 


\section{Acknowledgement}

336 This work was supported by the French Ministry of Research through the LEFE/CHAT

337 program. This work was also sponsored in part by the region of Alsace and the REseau Alsace

338 de Laboratoires en Ingénierie et Sciences pour l'Environnement (REALISE).

339 


\section{References}

Allen, J.M., Balcavage, W.X., Ramachandran, B.R. and Shrout, A.L., 1998. Determination of Henry's law constant by equilibrium partitioning in a closed system using a new in situ optical absorbance method. Environ. Toxicol. Chem. 17, 1216-1221.

Atkinson, R., 1994. Gas-phase tropospheric chemistry of organic compounds. Journal of physical and chemical reference data., J. Phys. Chem. Ref. Data, Monograph No. 2. American Chemical Society; American Institute of Physics for the National Institute of Standards and Technology, Washington, Woodbury, iii, 216 pp.

Atkinson, R., 2000. Atmospheric chemistry of VOCs and NOx. Atmos. Envir. 34, 2063-2101.

Atkinson, R., Carter, W.P.L., Plum, C.N., Winer, A.M. and Pitts, J.N., 1984. Kinetics of the gas - phase reactions of $\mathrm{NO}_{3}$ radicals with a series of aromatics at $296 \pm 2 \mathrm{~K}$ Int. J. Chem. Kinet. 16, 887-898.

Betterton, E.A. and Hoffmann, M.R., 1988. Henry's Law constants of some environmentally important aldehydes. Environ. Sci. Technol. 22, 1415-1418.

Chameides, W.L., 1984. The photochemistry of a remote marine stratoform cloud. J. Geophys. Res. 89D, 4739.

Chin, M. and Wine, P.H., 1994. Aquatic and surface photochemistry. CRC Press, Boca Raton, FL.

Danckwerts, P.V., 1970. Gas-liquid reactions. McGraw-Hill Book Co., New York,, xiii, 276 pp.

Dong, S. and Dasgupta, P.K., 1986. Environ. Sci. Technol. 20, 637-640.

Ervens, B., Gligorovski, S. and Herrmann, H., 2003. Temperature-dependent rate constants for hydroxyl radical reactions with organic compounds in aqueous solutions. Phys. Chem. Chem. Phys. 9, 1811-1824.

Feigenbrugel, V., Le Calvé, S. and Mirabel, P., 2004a. Henry's law constants measurements of metolachlor and diazinon between 283 and 298 K. Chemosphere 59, 319-327.

Feigenbrugel, V., Le Calvé, S., Mirabel, P. and Louis, F., 2004b. Henry's Law Constants measurements for phenol, o-, m-, and p-cresol as a function of temperature. Atmos. Environ. 38, 5577-5588.

Gaffney, J.S. and Senum, G.I., 1984. Gas-Liquid Chemistry of Natural Waters. In: e. In L. Newman (Editor), NTIS TIC-4500, UC-11, BNL 51757 Brookhaven National Laboratory, pp. pages 5-1-5-7.

Gao, R.S., Popp, P.J., Fahey, D.W., Marcy, T.P., Herman, R.L., Weinstock, E.M., Baumgardner, D.G., Garrett, T.J., Rosenlof, K.H., Thompson, T.L., Bui, P.T., Ridley, B.A., Wofsy, S.C., Toon, O.B., Tolbert, M.A., B., K., Peter, T., Hudson, P.K., Weinheimer, A.J. and Heymfield, A.J., 2004. Evidence That Nitric Acid Increases Relative Humidity in Low-Temperature Cirrus Clouds Science 23, 516 - 520.

Gautier, C., Le Calvé, S. and Mirabel, P., 2003. Henry's law constants measurements of alachlor and dichlorvos between 283 and 298 K. Atmos. Environ. 37, 2347-2353.

Gunz, D. and Hoffmann, M.R., 1990. Atmospheric chemistry of proxides: A review. Atmos. Environ. 24A, 1601-1633. 
Hine, J. and Mookerjee, P.K., 1975. The intrinsic hydrophilic character of organics compounds. J. Org. Chem. 40, 292-298.

IUPAC, 2008, subcommitee on gas kinetic data evaluation-data sheet HOx_VOC12, http://www.iupac-kinetic.ch.cam.ac.uk.

Jayne, J.T., Worsnop, D.R., Kolb, C.E., Swartz, E. and Davidovits, P., 1996. Uptake of GasPhase Formaldehyde by Aqueous Acid Surfaces. J. Phys. Chem. 100, 8015-8022.

Katrib, Y., Le Calvé, S. and Mirabel, P., 2003. Uptake measurements of dibasic esters by water droplets and determination of their Henry's law constants. J. Phys. Chem. A 107, 11433-11439.

Khare, P., Satsangi, G.S., Kumar, N., Kumari, M.K. and Srivastava, S.S., 1997. HCHO, $\mathrm{HCOOH}$ and $\mathrm{CH} 3 \mathrm{COOH}$ in air and rain water ata rural tripical site in north central India. Atmos. Environ. 31, 3867-3875.

Kieber, R.J., Rhines, M.F., J.D., W. and Avery, J.G.B., 1999. Rainwater formaldehyde : concentration, deposition and photochemical formation. Atmos. Envir. 33, 3659-3667.

Kolb, C.E., 1994. Laboratory studies of atmospheric heterogeneous chemistry. In: I.B.J. (Ed) (Editor), Advances in Physical Chemistry Series, World Scientific, Singapore, pp. 771-875.

Levart, A. and Veber, M., 2001. Determination of aldehydes and ketones in air samples using cryotrapping sampling. Chemosphere 44, 701-708.

Marchand, C., Bulliot, B., Le Calvé, S. and Mirabel, P., 2006. Aldehyde Measurements in indoor environment in Strasbourg (France). Atmos. Environ. 40, 1336-1345.

Marchand, C., Le Calvé, S., Mirabel, P., N., G., Casset, A., Schneider, N. and F., d.B., 2008. Indoor aldehydes concentrations and determinants in 162 homes in Strasbourg (France). Atmos. Environ. 42, 505-516.

Masclet, P., 2005. Pollution atmosphérique : Causes, conséquences, solutions, perspectives.

McDonald, R.S. and Martin, E.V., 1979. The kinetics and equilibrium of the hydration of phthalaldehyde. Can. J. Chem. 57, 506-516

McElroy, C.T., Salawitch, R.J. and Minschwaner, K., 1992. The changing stratosphere. Planet. Space Sci. 40, 373-401.

Monod, A. and Carlier, P., 1999. Impact of clouds on the tropospheric ozone budget: Direct effect of multiphase photochemistry of soluble organic compounds. Atmos. Environ. $33,4431-4446$.

Monod, A., Poulain, L., Grubert, S., Voisin, D. and Wortham, H., 2005. Kinetics of OHinitiated oxydation of oxigenated organic compounds in the aqueous phase: new rate constants, structureactivity relationships and atmospheric implications. Atmos. Environ. 39, 7667-7688.

Mora-Diez, N. and Boyd, R.J., 2002. A Computational Study of the kinetics of the NO3 Hydrogen-Abstraction Reaction from a series of Aldéhydes (XCHO : $\mathrm{X}=\mathrm{F}, \mathrm{Cl}, \mathrm{H}$, CH3). J. Phys. Chem. A 106, 384-394.

Müller, K., 1997. Determination of aldehydes and ketones in the atmosphere : A comparative long time study at an urban and a rural site in Eastern germany. Chemosphere 35, 2093-2106. 
Munger, J.W., Tiller, C. and Hoffmann, M.R., 1986. Identification of hydroxymethansulfonate in fog water. Science 231, 247-249.

NIST, NIST solution kinetics database, http://www.rcdc.nd.edu/browse_compil.html.

Nuccio, J., Seaton, P.J. and Kieber, R.J., 1995. Biological production of formaldehyde in the marine environment. Limnology and oceanography 40, 521-527.

Rice, C.P., Chernyak, S.M. and Mc Connell, L.L., 1997. Henry's Law Constants for pesticides measured as a function of temperature and salinity. J. Agric. Food Chemistry 45, 2291-2298.

Riedel, K., Weller, R. and Schrems, O., 1999. Variability of formaldehyde in the Antarctic troposphere. Phys. Chem. Chem. Phys. 1, 5523-5528.

Seinfeld, J.H., 1986. Atmospheric Chemistry and Physic of Air Pollution. ed. J. Wiley \& Sons, New York.

Semadeni, M., Stocker, D.W. and Kerr, J.A., 1995. The temperature dependance of the OH radical reactions with some aromatic compounds under simulated tropospheric conditions. Int. J. Chem. Kinet. 27, 287-304.

Setschenow, S., 1889. Über die Konstitution der Salzlösungen auf Grund ihres Verhaltens zu Kohlensäure. Zerichte für Physikalische Chemie 4, 117-125.

Seyfioglu, R. and Odabasi, M., 2007. Determination of of Henry's law constant of formaldehyde as a function of temperature: Application to air-water exchange in Tahtali Lake in Izmir, Turkey. Environmental Monitoring and Assessment 128, 343349.

Smith, C.A., Pope, F.D., Cronin, B., Parkes, C.B. and Orr-Ewing, A.J., 2006. Absorption Cross sections of formaldehyde at wavelenths from 300 to $340 \mathrm{~nm}$ at 294 and 245K. J. Phys. Chem. A 110, 11645-11653.

Sprengnether, M., Demerjian, K.L., Donahue, N.M. and Anderson, J.G., 2002. Product analysis of the $\mathrm{OH}$ oxidation of isoprene and 1,3-butadiene in the presence of NO. J. Geophys. Res. 107, 4268-4281.

Staudinger, J. and Roberts, P.J., 1996. A critical review of Henry's law constants for environmental applications. Crit. Rev. Environ. Sci. Technol. 26, 205-297.

Swartz, E., Boniface, J., Tchertkov, I., Rattigan, O.V., Robinson, D.V., Davidovits, P., Worsnop, D.R., Jayne, J.T. and Kolb, C.E., 1997. Horizontal bubble train apparatus for heterogeneous chemistry studies : Uptake of gas-phase formaldehyde. Environ. Sci. Technol. 31, 2634-2641.

Warneck, P., 1988. Chemistry of the natural atmosphere. International geophysics series ; v. 41. Academic Press, San Diego, xiii, 757 pp.

Williams, I.D., Revitt, D.M. and Hamilton, R.S., 1996. A comparison of carbonyl concentrations at urban roadsite and indoor sites. Sci. Total Environ. 189/190, 475483.

Zhou, X. and Mopper, K., 1990. Apparent partition coefficients of 15 carbonyl compounds between air and seawater and between air and freshwater; Implications for air-sea exchange. Environ. Sci. Technol. 24, 1864-1869. 
Zhu, L. and Cronin, T.J., 2000. Photodissociation of benzaldehyde in the 280-308 nm region. 465 Chem. Phys. Lett. 317, 227-231. 
469 Figure 1 : Scheme of the dynamic equilibrium system used to determine Henry's law 470 constants as a function of the temperature.

471 Figure 2 : Plot of $\ln H$ versus $1000 / T$ for formaldehyde in the temperature range $273-293 \mathrm{~K}$ 472 in deionized water. Our determinations are compared to the experimental data of the 473 literature. Our uncertainties on $H$ values varied typically between 8 and $20 \%$ and are 474 determined as mentioned in the text. Straigth lines represent Arrhenius plots derived by 475 Staudinger and Roberts (blue dash-dot line), by Zhou and Mopper (red long dash line), by 476 Betterton and Hoffmann (green dash-dot line), by Chameides (black dotted line) or in this 477 work (pink solid line).

478 Figure 3 : Plot of $\ln H$ versus 1000/T for benzaldehyde in the temperature range $273-293 \mathrm{~K}$ 479 in deionized water. Our determinations are compared to the experimental data of the 480 literature. Our uncertainties on $H$ values varied typically between 8 and $20 \%$ and are 481 determined as mentioned in the text. Straigth lines represent Arrhenius plots derived by Allen 482 et al. (black long dash line), by Staudinger and Roberts (blue dash-dot line), by Zhou and 483 Mopper (red long dash line), by Betterton and Hoffmann (green dash-dot line) or in this work 484 (pink solid line).

485 Figure 4 : Plot of $H$ versus the flow rate ranging between 0.2 and $0.5 \mathrm{~L} \mathrm{~min}^{-1}$ for both 486 formaldehyde and benzaldehyde at $293 \mathrm{~K}$. Our errors on $H$ varied typically between 8 and 20 $487 \%$ and are determined as mentioned in the text.

488 Figure 5 : Plot of $\ln H$ versus 1000/T for formaldehyde in $0.1 \mathrm{~N}$ (dotted line) and $1 \mathrm{~N}$ (dash 489 line) nitric acid solutions in the temperature range $273-293 \mathrm{~K}$ and comparison with values 490 obtained in in deionized water (solid line).

491 Figure 6 : Plot of $\ln H$ versus 1000/T for benzaldehyde in $0.1 \mathrm{~N}$ and $1 \mathrm{~N}$ nitric acid (dash line

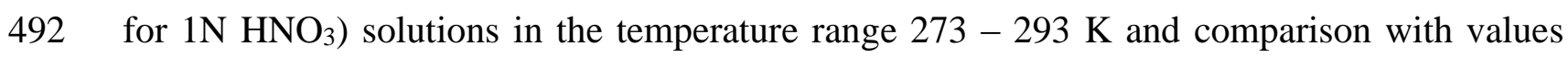
493 obtained in in deionized water (solid line). 
494 Figure 7 : Plot of $\ln H$ versus 1000/T in deionized water (solid line) and salt water (dash line) 495 for formaldehyde in the temperature range $273-293 \mathrm{~K}$.

496 Figure 8 : Plot of $\ln H$ versus $1000 / T$ in deionized water (solid line) and salt water (dash line) 497 for benzaldehyde in the temperature range $273-293 \mathrm{~K}$.

498 
Table 1: Henry's Law Constants of benzaldehyde and formaldehyde as a function of the 500 temperature determined by using the dynamic equilibrium system.

\begin{tabular}{|c|c|c|}
\hline$T(\mathbf{K})$ & $\boldsymbol{H}$ Formaldéhyde & $\boldsymbol{H}$ benzaldehyde \\
\hline 273.05 & - & $248 \pm 17^{\mathrm{e}}$ \\
\hline 273.05 & - & $261 \pm 23$ \\
\hline 273.15 & $22600 \pm 2200$ & $237 \pm 22$ \\
\hline 273.15 & $27500 \pm 3200$ & - \\
\hline 273.25 & $29600 \pm 3400$ & - \\
\hline 273.35 & $22800 \pm 2100$ & - \\
\hline 278.05 & - & $144 \pm 13$ \\
\hline 278.15 & $17100 \pm 1400$ & - \\
\hline 278.25 & - & $150 \pm 14$ \\
\hline 278.75 & - & $145 \pm 10^{\mathrm{e}}$ \\
\hline 283.15 & $11000 \pm 900$ & $100 \pm 9$ \\
\hline 283.15 & $9940 \pm 1260$ & - \\
\hline 283.45 & - & $97 \pm 7^{\mathrm{e}}$ \\
\hline 283.45 & - & $103 \pm 7^{\mathrm{e}}$ \\
\hline 288.15 & $7390 \pm 610$ & $73 \pm 7$ \\
\hline 288.35 & $7300 \pm 680$ & \\
\hline 288.45 & - & $69 \pm 5^{e}$ \\
\hline 288.45 & - & $71 \pm 5^{\mathrm{e}}$ \\
\hline 292.95 & - & $50 \pm 5^{a}$ \\
\hline 292.95 & - & $46 \pm 3^{b}$ \\
\hline 293.05 & $5300 \pm 840$ & $46 \pm 3^{e}$ \\
\hline 293.05 & $5330 \pm 500^{b}$ & $50 \pm 4^{\mathrm{e}}$ \\
\hline 293.15 & - & $49 \pm 3^{c}$ \\
\hline 293.15 & $5230 \pm 520^{a}$ & $54 \pm 5$ \\
\hline 293.15 & - & $46 \pm 4$ \\
\hline 293.25 & $5530 \pm 400^{\mathrm{c}, \mathrm{d}}$ & $49 \pm 3^{\mathrm{e}}$ \\
\hline 293.35 & - & $49 \pm 3^{\mathrm{e}}$ \\
\hline 293.35 & - & $53 \pm 4^{\mathrm{e}}$ \\
\hline
\end{tabular}

501 By default, the experiments were carried out in deionized water with a flow rate of $0.4 \mathrm{~L} \mathrm{~min}^{-1}$ 502 and with an aqueous concentration of $\sim 15 \mathrm{mg} \mathrm{L}^{-1}\left(\sim 5 \times 10^{-4} \mathrm{M}\right)$ for formaldehyde and $\sim 10 \mathrm{mg}$ $503 \mathrm{~L}^{-1}\left(\sim 9.4 \times 10^{-5} \mathrm{M}\right)$ for benzaldehyde. Experiments carried out with an air flow rate of: ${ }^{\text {a }} 0.2 \mathrm{~L}$ 
$504 \mathrm{~min}^{-1} ;{ }^{\mathrm{b}} 0.3 \mathrm{~L} \mathrm{~min}^{-1} ;{ }^{\mathrm{c}} 0.5 \mathrm{~L} \mathrm{~min}^{-1}$. Experiments performed with an aqueous concentration of: ${ }^{\mathrm{d}}$

$505 \sim 85 \mathrm{mg} \mathrm{L}^{-1}\left(\sim 2.8 \times 10^{-3} \mathrm{M}\right)$ for formaldehyde; ${ }^{\mathrm{e}} \sim 25 \mathrm{mg} \mathrm{L}^{-1}\left(\sim 2.4 \times 10^{-4} \mathrm{M}\right)$ for benzaldehyde. 
Table 2: Comparison of experimental Henry's law constants for formaldehyde with previous

\begin{tabular}{|c|c|c|c|c|c|}
\hline $\begin{array}{c}T \\
(\mathbf{K}) \\
\end{array}$ & $\begin{array}{c}H \\
\left(\mathrm{M} \mathbf{a t m}^{-1}\right)\end{array}$ & $\begin{array}{c}\mathrm{d} \ln H / \mathrm{d}(1 / T) \\
(\mathrm{K}) \\
\end{array}$ & $\begin{array}{c}T \text { range } \\
(\mathbf{K}) \\
\end{array}$ & Technique & Référence \\
\hline 298 & $6.0 \times 10^{3}$ & - & - & $-{ }^{a}$ & (Gaffney and Senum, 1984) \\
\hline $\begin{array}{l}293 \\
298\end{array}$ & $\begin{array}{l}1.0 \times 10^{4} \\
7.0 \times 10^{3} \\
\end{array}$ & 6400 & & $\mathrm{TC}^{\mathrm{b}}$ & (Chameides, 1984) \\
\hline 298 & $6.3 \times 10^{3}$ & - & & $-{ }^{a}$ & (Seinfeld, 1986) \\
\hline $\begin{array}{r}293 \\
298 \\
\end{array}$ & $\begin{array}{l}4.5 \times 10^{3} \\
3.0 \times 10^{3} \\
\end{array}$ & 7200 & $278-318$ & $\mathrm{SCT}^{\mathrm{c}}$ & $\begin{array}{l}\text { (Betterton and Hoffmann, } \\
\text { 1988) }\end{array}$ \\
\hline 298 & $1.4 \times 10^{4}$ & - & & $-{ }^{a}$ & (Warneck, 1988) \\
\hline $\begin{array}{l}293 \\
298\end{array}$ & $\begin{array}{l}4.5 \times 10^{3} \\
3.1 \times 10^{3} \\
\end{array}$ & 6500 & $283-318$ & $\mathrm{SCT}^{\mathrm{c}}$ & (Zhou and Mopper, 1990) \\
\hline $\begin{array}{r}293 \\
298 \\
\end{array}$ & $\begin{array}{l}4.7 \times 10^{3} \\
3.2 \times 10^{3} \\
\end{array}$ & 6800 & - & SEST $^{d}$ & $\begin{array}{c}\text { (Staudinger and Roberts, } \\
1996)\end{array}$ \\
\hline $\begin{array}{l}293 \\
298 \\
\end{array}$ & $\begin{array}{l}5.9 \times 10^{3} \\
5.4 \times 10^{3} \\
\end{array}$ & 1642 & $278-323$ & $\mathrm{SCT}^{\mathrm{c}}$ & (Seyfioglu and Odabasi, 2007) \\
\hline $\begin{array}{l}293 \\
298\end{array}$ & $\begin{array}{l}(5.0 \pm 1.2) \times 10^{3 \mathrm{f}} \\
(3.5 \pm 0.8) \times 10^{3 \mathrm{f}}\end{array}$ & $6423 \pm 542^{f}$ & $273-293$ & $\mathrm{DES}^{\mathrm{e}}$ & This work \\
\hline
\end{tabular}

$510{ }^{\text {a }}$ not reported; ${ }^{\mathrm{b}}$ Thermodynamic calculation; ${ }^{\mathrm{c}}$ SCT: Stripping Column Technique; ${ }^{\mathrm{d}}$ SEST:

511 Single Equilibrium Static Technique; ${ }^{\mathrm{e}}$ DES: Dynamic Equilibrium System; ${ }^{\mathrm{f}}$ The quoted

512 errors correspond to $2 \sigma$ obtained from the least-squares analysis. 
514 Table 3: Comparison of experimental Henry's law constants for benzaldehyde with previous 515 work.

516

\begin{tabular}{|c|c|c|c|c|c|}
\hline $\mathbf{T}(\mathbf{K})$ & $\begin{array}{c}\text { H } \\
\left(\text { M.atm }^{-1}\right) \\
\end{array}$ & $\begin{array}{c}d \ln H / d(1 / T) \\
(K)\end{array}$ & $\begin{array}{c}\text { T range } \\
(\mathrm{K})\end{array}$ & Technique & Reference \\
\hline 298 & 36 & - & - & $\mathrm{SAR}^{\mathrm{a}}$ & $\begin{array}{c}\text { (Hine and Mookerjee, } \\
1975)\end{array}$ \\
\hline 298 & 36 & - & - & $-b$ & $\begin{array}{c}\text { (Gaffney and Senum, } \\
1984)\end{array}$ \\
\hline 293 & 50 & \multirow[t]{2}{*}{5100} & \multirow[t]{2}{*}{$278-318$} & \multirow{2}{*}{$\mathrm{SCT}^{\mathrm{c}}$} & \multirow{2}{*}{$\begin{array}{c}\text { (Betterton and Hoffmann } \\
1988)\end{array}$} \\
\hline 298 & 37 & & & & \\
\hline 293 & 55 & \multirow[t]{2}{*}{4600} & \multirow[t]{2}{*}{$283-318$} & \multirow{2}{*}{$\mathrm{SCT}^{\mathrm{c}}$} & \multirow[t]{2}{*}{ (Zhou and Mopper, 1990) } \\
\hline 298 & 42 & & & & \\
\hline 293 & 51 & \multirow[t]{2}{*}{4800} & \multirow[t]{2}{*}{-} & \multirow[t]{2}{*}{ SEST $^{d}$} & \multirow{2}{*}{$\begin{array}{c}\text { (Staudinger and Roberts, } \\
1996)\end{array}$} \\
\hline 298 & 39 & & & & \\
\hline 293 & 52 & \multirow[t]{2}{*}{7000} & \multirow[t]{2}{*}{-} & \multirow[t]{2}{*}{$\mathrm{EPICS}^{\mathrm{e}}$} & \multirow{2}{*}{ (Allen et al., 1998) } \\
\hline 298 & 35 & & & & \\
\hline 293 & $47 \pm 5^{g}$ & \multirow[t]{2}{*}{$6260 \pm 280^{g}$} & \multirow[t]{2}{*}{$273-293$} & \multirow[t]{2}{*}{ DES ${ }^{f}$} & \multirow{2}{*}{ This work } \\
\hline 298 & $33 \pm 3^{g}$ & & & & \\
\hline
\end{tabular}

$517{ }^{\mathrm{a}}$ determined from Structure Activity Relationship; ${ }^{\mathrm{b}}$ not reported; ${ }^{\mathrm{c}}$ SCT: Stripping Column

518 Technique; ${ }^{\mathrm{d}}$ SEST: Single Equilibrium Static Technique; ${ }^{\mathrm{e}}$ Equilibrium Partitioning In

519 Closed Systems (EPICS); ${ }^{\mathrm{f}}$ DES: Dynamic Equilibrium System. ${ }^{\mathrm{g}}$ The quoted errors

520 correspond to $2 \sigma$ obtained from the least-squares analysis. 
Table 4: Rate constants of $\mathrm{OH}$ reaction with formaldehyde and benzaldehyde in both gas and aqueous phases and their corresponding Henry's law constants. The atmospheric lifetimes were calculated at two temperatures, i.e. 298 and $283 \mathrm{~K}$.

\begin{tabular}{|c|c|c|c|c|c|c|c|c|c|c|c|c|}
\hline \multirow[t]{2}{*}{ Compound } & \multicolumn{2}{|c|}{$\begin{array}{c}10^{12} \times \mathrm{k} \mathrm{OH}, \mathrm{g} \\
\left(\mathrm{cm}^{3} \mathrm{~s}^{-1}\right)\end{array}$} & \multicolumn{2}{|c|}{$\begin{array}{c}10^{-8} \times \mathrm{k} \mathrm{OH}, \text { aq } \\
\left(\mathrm{M}^{-1} \mathrm{~s}^{-1}\right)\end{array}$} & \multicolumn{2}{|c|}{$\begin{array}{c}10^{5} \times \mathbf{J g} \\
\left(\mathrm{s}^{-1}\right)\end{array}$} & \multicolumn{2}{|c|}{$\begin{array}{c}\text { H } \\
\left(\mathbf{M ~ a t m}^{-1}\right)\end{array}$} & \multicolumn{2}{|c|}{$\begin{array}{c}\tau \text { multyiphase } \\
\text { January } \\
\text { (hours) }\end{array}$} & \multicolumn{2}{|c|}{$\begin{array}{c}\tau \text { multiphase } \\
\text { July } \\
\text { (hours) }\end{array}$} \\
\hline & $298 \mathrm{~K}$ & $283 K$ & $298 \mathrm{~K}$ & $283 \mathrm{~K}$ & January & July & 298K & $283 \mathrm{~K}$ & $298 K$ & $283 \mathrm{~K}$ & $298 \mathrm{~K}$ & $283 \mathrm{~K}$ \\
\hline Formaldehyde & $8.5^{\mathrm{a}}$ & $8.7^{\mathrm{a}}$ & $7.6^{\mathrm{g}}$ & $6.3^{\mathrm{g}}$ & $3.2^{\mathrm{c}}$ & $7.3^{\mathrm{c}}$ & $3480^{h}$ & $10900^{\mathrm{h}}$ & 13.2 & 13.0 & 6.7 & 7.0 \\
\hline Benzaldehyde & $12^{\mathrm{d}}$ & $13^{\mathrm{d}}$ & $4.4 \times 10^{4 i}$ & $4.4 \times 10^{4 i}$ & $0.15^{\mathrm{f}}$ & $1.5^{\mathrm{f}}$ & $37^{\mathrm{h}}$ & $111^{\mathrm{h}}$ & 3.1 & 1.2 & 2.9 & 1.2 \\
\hline
\end{tabular}

${ }^{\mathrm{a}}$ (IUPAC, 2009) ; ${ }^{\mathrm{b}}$ (Mora-Diez and Boyd, 2002) $;{ }^{\mathrm{c}}$ (Masclet, 2005) $;{ }^{\mathrm{d}}$ (Semadeni et al., 1995) ; ${ }^{\mathrm{e}}$ (Atkinson et al., 1984) ; ${ }^{\mathrm{f}}($ Zhu and Cronin, 2000) ${ }^{\mathrm{g}}$ (Chin and Wine, 1994) ${ }^{\mathrm{h}}$ This work; ${ }^{\mathrm{i}}$ (NIST, 2009). 
Dilution air $\left(Q_{2}=0.5 \mathrm{~L} \mathrm{~min}^{-1}\right)$

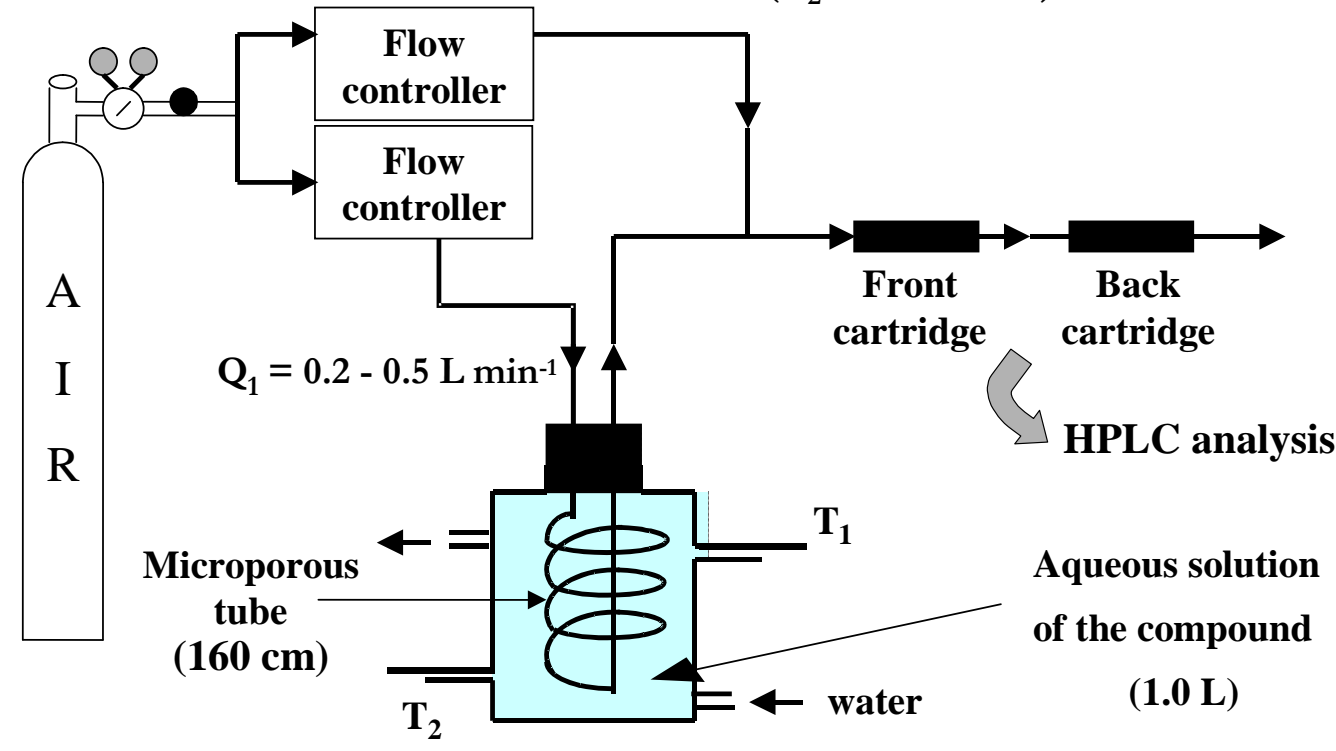

Figure 1

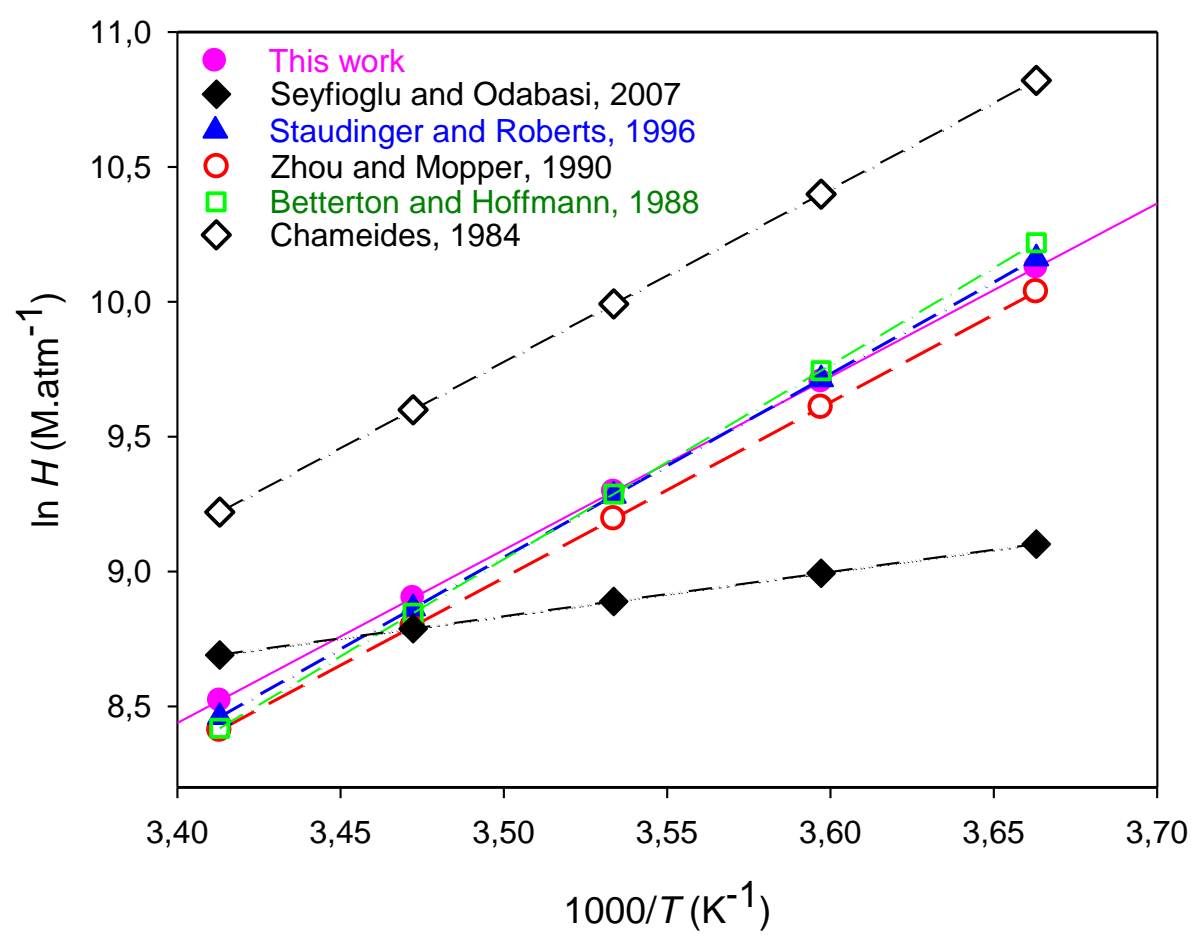

Figure 2 


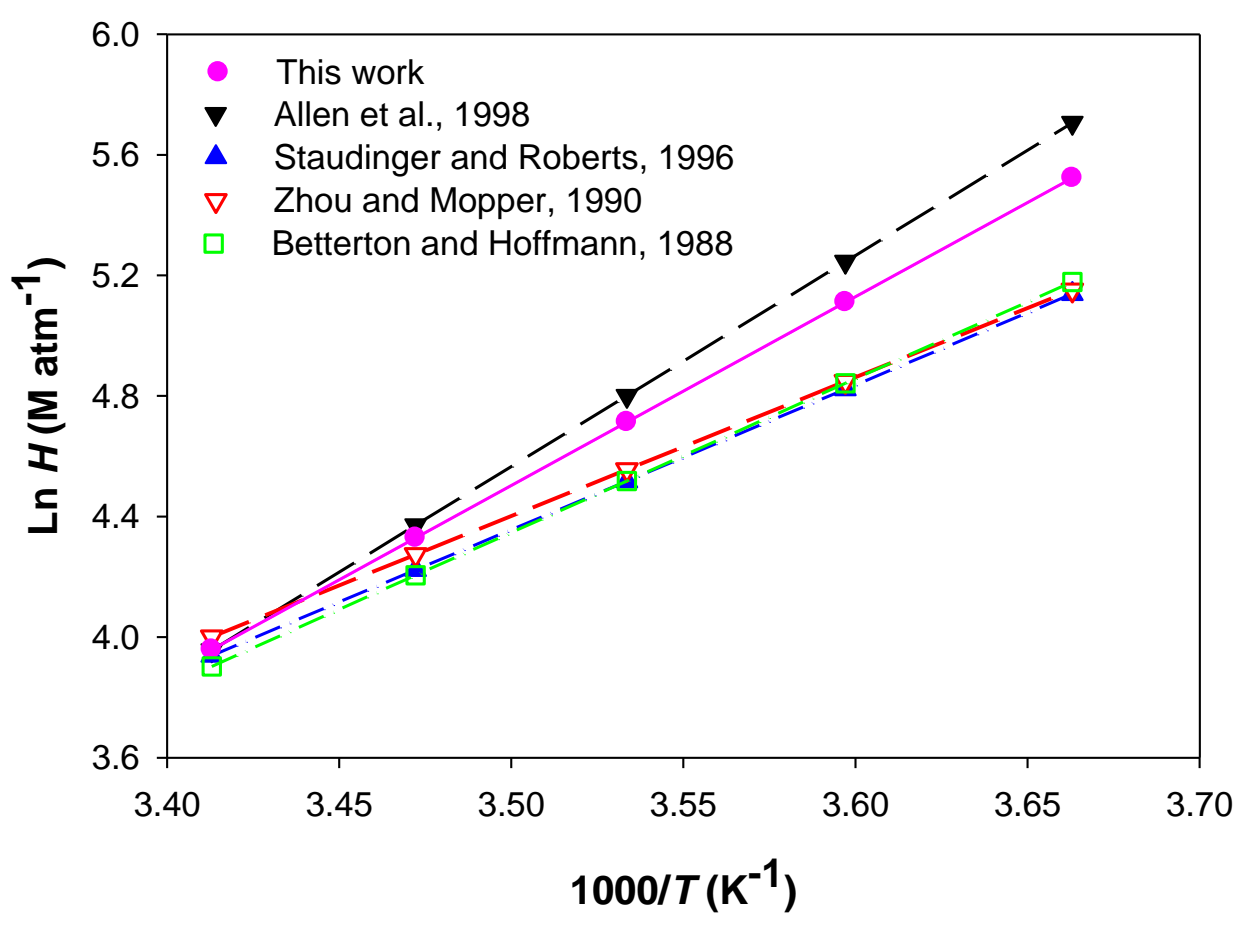

Figure 3

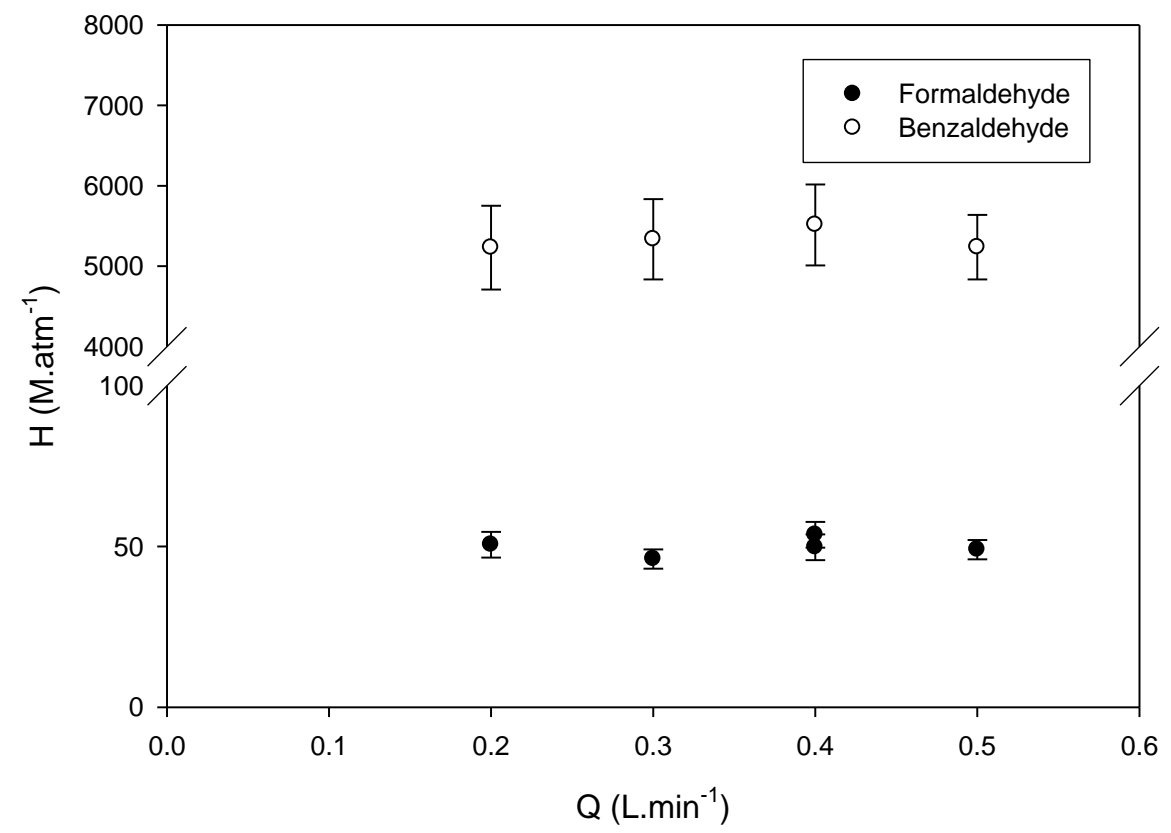

Figure 4 


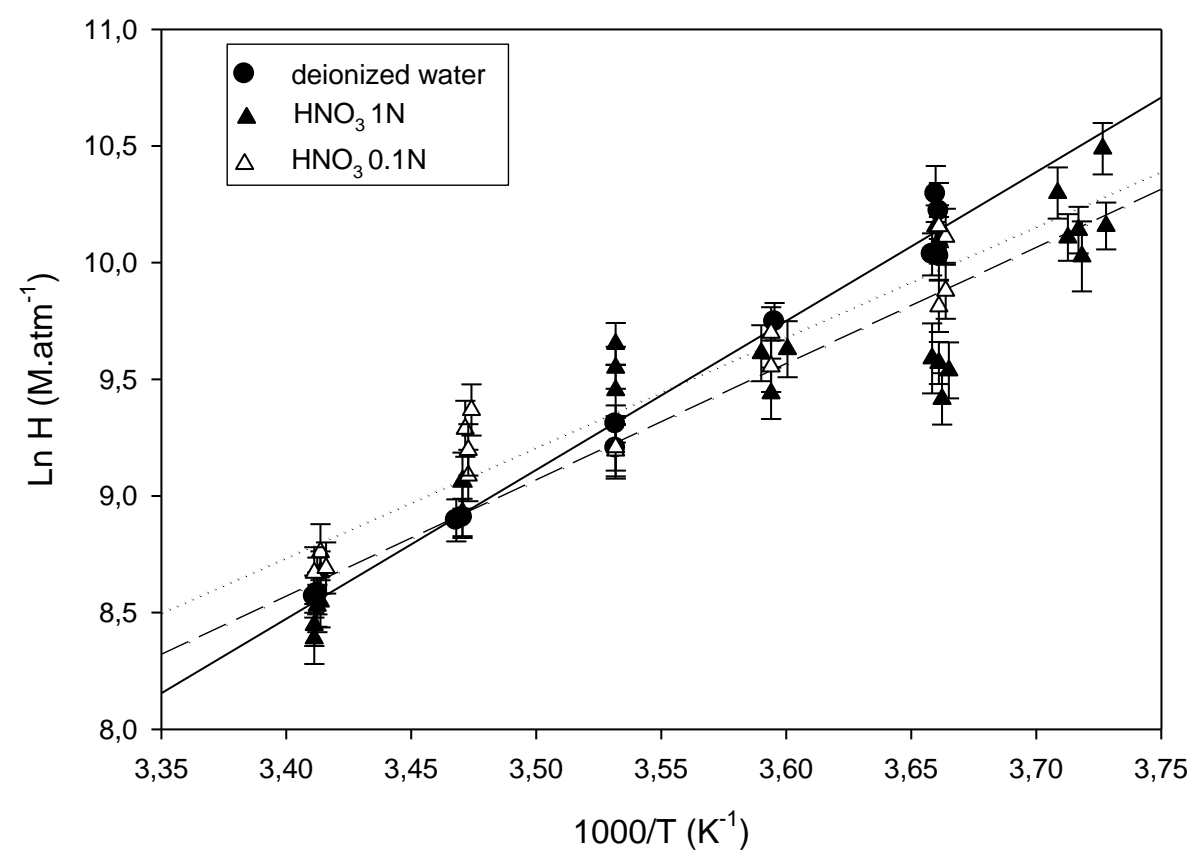

Figure 5

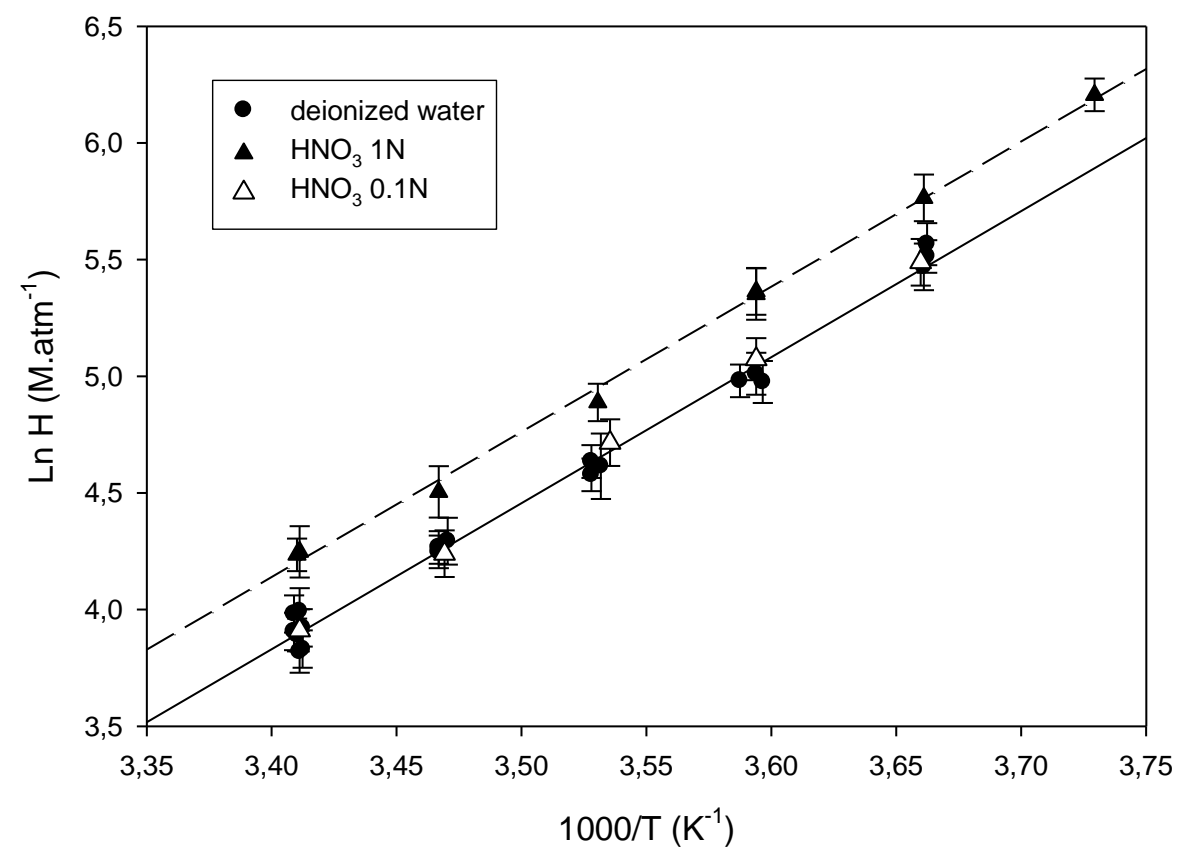

Figure 6 


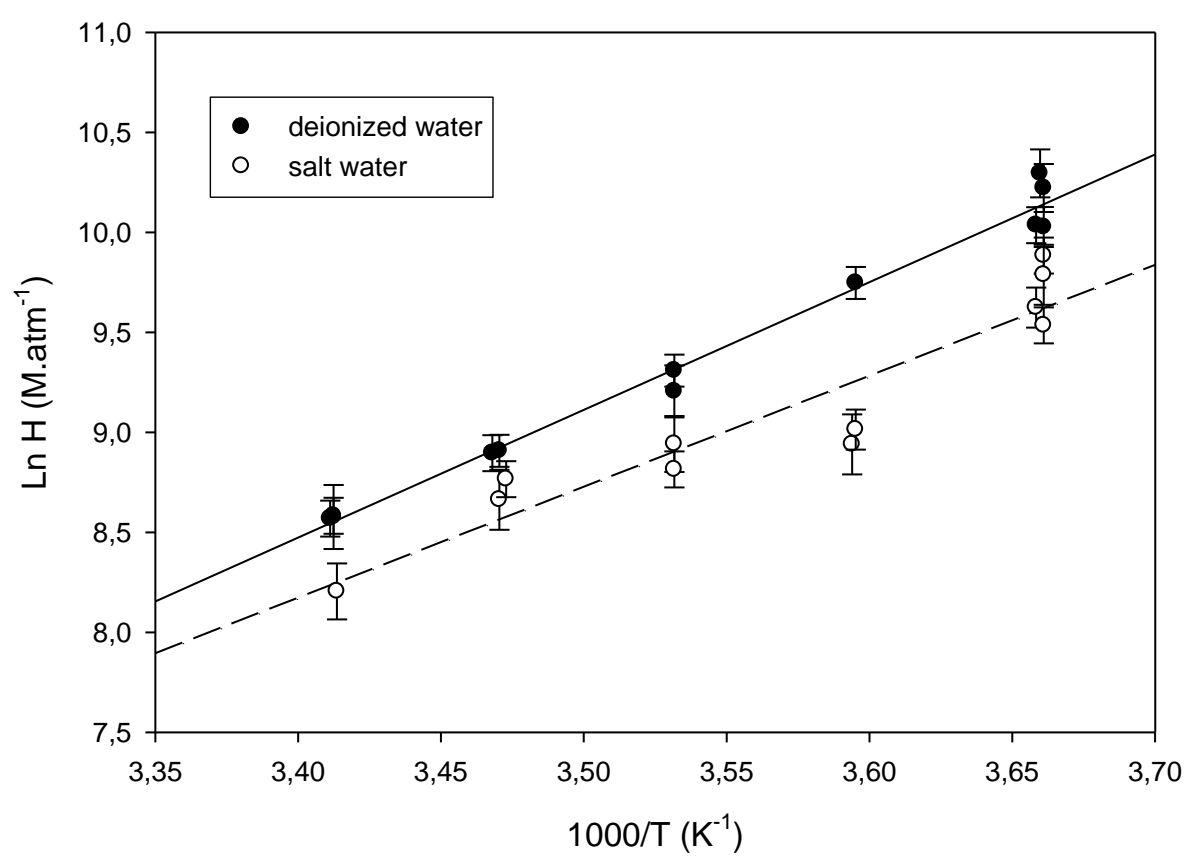

Figure 7

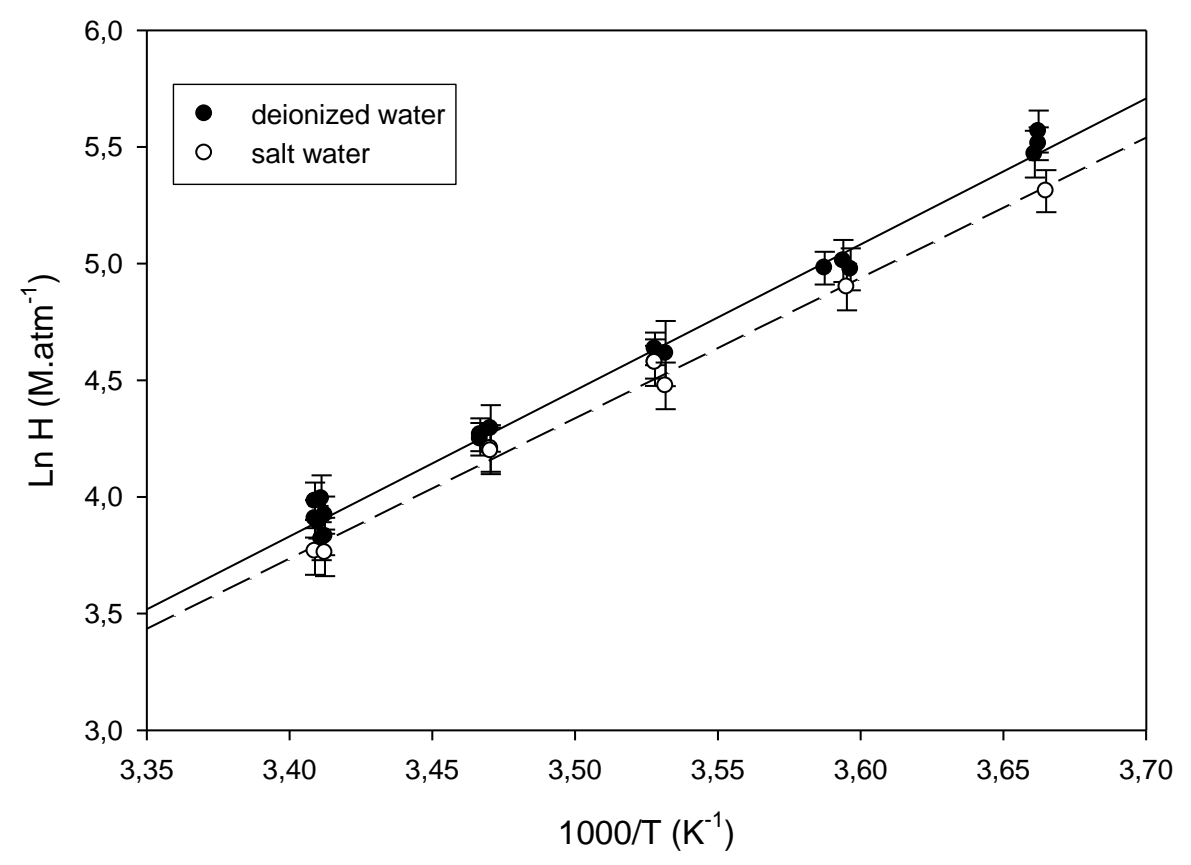

Figure 8 